\title{
MACROECONOMIC TOOLS FOR ENSURING RESILIENCE OF THE FINANCIAL CORPORATIONS SECTOR
}

\author{
Diana Shkuropadska \\ Department of economic theory and competition policy \\ Kyiv National University of Trade and Economics \\ 19 Kioto str., Kyiv, Ukraine, 02156 \\ diana.2412y@gmail.com
}

\begin{abstract}
Research the tools for ensuring resilience of the financial corporations sector is relevant, given the fact that the development of the world economy is increasingly subject to the shock influences, to which financial crises are imposed.

The aim of the article is to identify and justify macroeconomic tools according to the directions for ensuring resilience of the financial corporations sector.

The theoretical-methodological base of the article is scientific works of scientists and reports of international organizations for directions and tools for ensuring resilience of the financial corporations sector and the economy in general. The general approaches and research methods have been used at preparing the article: theoretical generalization, analysis, synthesis and system method.

The use of these methods allowed to consider approaches of leading international audit companies to understand the concept "resilience of the financial corporations". On this basis, there was suggested the author's definition of the concept "resilience of the financial corporations sector" and defined it essential characteristics.

It was explained, that the process of ensuring resilience of the financial corporations sector involves the implementation of macroeconomic tools in accordance with the following areas: the introduction of economic stimulus packages, attractive lending conditions, tax and investment benefits, promoting innovation, development of compensation mechanisms, international financial support.

The important attention in the study was paid to the role of the state in the process of implementing macroeconomic tools for ensuring resilience of the financial corporations sector. Attention is focused on the fact, that under shock influences the state should implement macroeconomic tools in line with current problems in the development of the financial corporations sector. This in turn will ensure its profitability at a level sufficient for normal functioning.
\end{abstract}

Keywords: resilience, financial corporations sector, shock influences, macroeconomic tools, economy.

DOI: $10.21303 / 2504-5571.2020 .001110$

\section{Introduction}

In the conditions of international integration, national economies are becoming more open, this increases their vulnerability to shock influences. In connection with the cyclical development of the world economy, the negative impact of the current financial and economic crises is expected to increase: crises are becoming global, shock influences are the most ambitious primarily in the financial corporations sector and then spread to other sectors of the economy. Building a resilient sector of financial corporations is one of the key tasks for most countries of the world. The financial corporations sector provides the economy with cash flows, generates financial resources for investment purposes, provides financial services for the development of industries, sectors and the consumer market. In the conditions of the rapid spread of crisis phenomena in the world economic space, there is a need to investigate the problem of the tools for ensuring resilience of the financial corporations sector.

The problem of ensuring the resilience of the economy and the sector of financial corporations is actively researched by both scientists and international organizations. The Organization for Economic Co-operation and Development (OECD) believes, that resilience of economy is ensured through the effective policy, aimed at mitigating the risks and consequences of crises. Such a policy should provide for monitoring the vulnerabilities of our own production and mechanisms to combat the effects of the economic downturn [1].

The European Commission (EC) is researching the areas of resilience of economy. The European Commission allocates key areas for ensuring resilience of economy: maintaining employment rates; ensuring financial stability; support for regional policy in order to reduce disparities in the development of depressed regions; financial assistance to countries in difficulty with budget finan- 
cing [2]. The European Commission uses such financial tools as the Structural Funds, which aimed at implementing these areas of resilience of economy. The International Monetary Fund implements the tools for ensuring resilience of the financial system. Such tools include: loan agreements, technical assistance, overseeing the monetary policy of member countries [3].

A. Boiko substantiated the basic tools for ensuring resilience of the national economy in accordance with such directions of public policy: fiscal, investment, social, foreign economic, monetary and industrial-agrarian [4]. S. Kozlovsky proposed the classification of key tools for ensuring resilience of the economic system behind such directions of state regulation: fiscal regulation, investment regulation, social regulation, monetary regulation, foreign economic regulation, business regulation, industrial regulation, energy regulation, indicative regulation [5]. S. Argyroudis has developed risk management tools, which ensure the adaptation and readiness of the system to counter various hazards [6]. Despite significant advances in the study of the problem of ensuring the resilience of the economy, questions about tools for ensuring resilience of the financial corporations sector remains open.

Aim of research. The main aim of the research is to define and justify macroeconomic tools by directions of ensuring resilience of the financial corporations sector.

\section{Materials and Methods}

The theoretical and methodological basis of the study is general scientific and special methods of scientific knowledge, the application of which made it possible to achieve the goal. In particular, the application of methods of theoretical generalization and analysis allowed to determine the essence of the concept of "resilience of the financial corporations". The use of the synthesis method has made it possible to identify macroeconomic tools in accordance with the areas of ensuring resilience of the financial corporations sector. According to the Classification of institutional sectors of the economy, the financial corporations sector is a collection of corporations, specializing in financial services or ancillary financial activities [7]. The structure of the financial corporations sector is presented in Fig. 1.

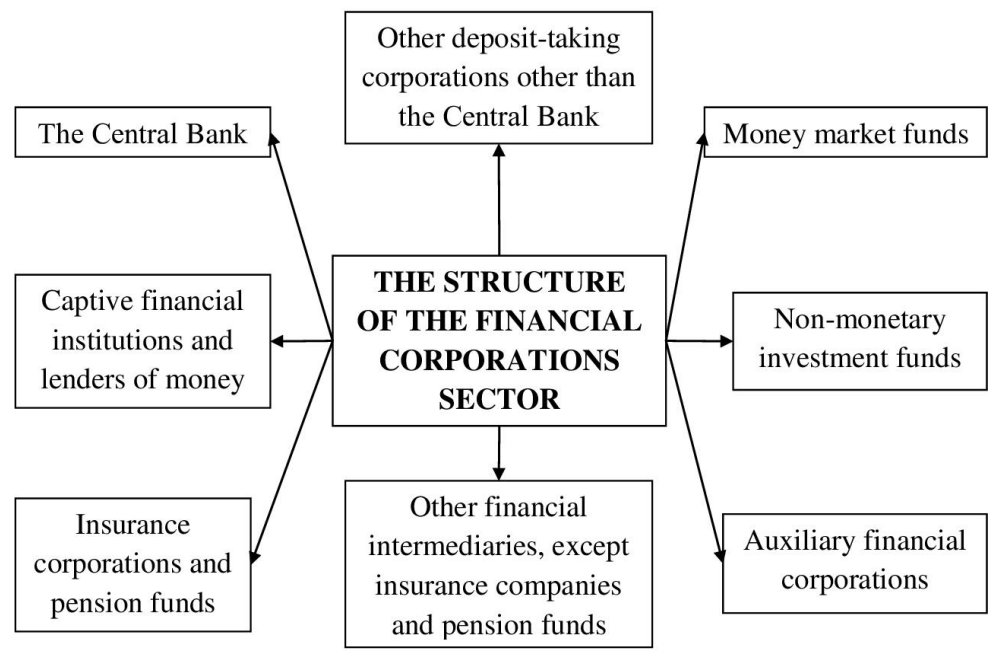

Fig. 1. The structure of the financial corporations sector [8]

The financial corporations sector includes: the Central Bank; other deposit and credit corporations (commercial banks); financial and intermediary organizations (investment corporations and corporations, engaged in financial leasing); ancillary financial institutions (brokerage, dealer firms that conduct transactions with securities); insurance organizations and pension funds. The main income of this sector is income from credit and deposit operations, interest and insurance premiums.

The need to study the resilience of financial corporations is due to the fact that in the period of globalization their role is constantly increasing. Financial corporations become the main economic agents of the national and world economy. Based on methods of analysis and systematiza- 
tion, there were analyzed key approaches to understanding the meaning of the concept «resilience of financial corporations» (Table 1).

Table 1

Key approaches to defining the concept "resilience of financial corporations"

\begin{tabular}{|c|c|c|}
\hline No. & Audit company & The content of the concept "resilience of financial corporations" \\
\hline 1 & Ernst \& Young & $\begin{array}{l}\text { is defined as the ability of firms, financial market infrastructures and the system as a whole to prep } \\
\text { vent, adapt and respond to, and recover and learn from, operational disruption [9] }\end{array}$ \\
\hline 2 & KPMG & $\begin{array}{l}\text { the ability of firms and the financial system as a whole to absorb and adapt to shocks, rather than } \\
\text { contribute to them [10] }\end{array}$ \\
\hline 3 & $\begin{array}{c}\text { Price } \\
\text { WaterhouseCoopers }\end{array}$ & $\begin{array}{l}\text { the ability to protect and sustain the core business services that are key for its clients, both during } \\
\text { business as usual and when experiencing operational stress or disruption [11] }\end{array}$ \\
\hline 4 & BDO & the ability to prevent, respond to, recover and learn from operational disruptions [12] \\
\hline 5 & $\begin{array}{l}\text { Deloitte Touche } \\
\text { Tohmatsu }\end{array}$ & $\begin{array}{l}\text { the ability to reduce the risk of major disruptions and to recover effectively and promptly after a } \\
\text { breach [13] }\end{array}$ \\
\hline 6 & Oliver Wyman & $\begin{array}{l}\text { the ability to continue to provide business services in the face of adverse operational events by } \\
\text { anticipating, preventing, recovering from, and adapting to such events [14] }\end{array}$ \\
\hline 7 & Milliman & the ability of firms to prevent, respond, recover and learn from operational disruptions [15] \\
\hline
\end{tabular}

Audit companies audit the activities of financial corporations for their resilience. An analysis of the approaches of international audit firms testifies to the affinity of views on the understanding of the concept of "resilience of financial corporations". Based on the systematic method, the essential characteristics of the resilience of the financial corporations sector were identified, which include:

- balance of financial flows;

- availability of sufficient funds to support its solvency and liquidity;

- profitable activity in conditions of shock influences;

- the ability to respond, prevent, and recover from shock influences.

The application of the method of theoretical generalization allowed us to determine the essence of the concept "resilience of the financial corporations sector". Thus, under the resilience of the financial corporation sector, one should understand the ability of financial corporations to prevent, respond and recover from shock influences, ensuring profitability at a level, sufficient to function properly in a competitive environment.

The key role that public authorities perform in the aftermath of shock influences on the financial corporation sector, - it is a stabilization of the situation through certain measures and tools.The second dimension of public policy is to foster economic recovery by helping financial corporations adapt to new circumstances.The ability to mobilize finances and resources at the national level is a key direction for the rapid recovery of the financial corporations sector after shock influences.

The analysis of the activities of such international organizations as the EC, IMF, OECD has identified the key areas of resilience of the financial corporations sector:

- economic stimulus packages;

- attractive credit conditions;

- tax and investment benefits;

- promoting innovation;

- compensation mechanisms;

- international financial support.

The need to develop the areas of resilience of the financial corporations sector should be considered in the context of the implementation of macroeconomic tools. The application of an effective set of tools will allow the least loss-making sector of the financial corporations to overcome the effects of shock influences.

\section{Results}

The financial corporations sector performs the functions of servicing the circulation of goods and services; ensures cash payments between economic entities; satisfies the borrowing 
needs of manufacturers and consumers; provides liquidity to real assets. Ensuring the resilience of financial corporations is one of the important tasks, given that the economic situation in the financial markets is increasingly characterized by instability.

Having identified the areas of resilience of the financial corporations sector, in the context of these areas will be appropriate to propose a system of macroeconomic tools. Macroeconomic tools are a set of tools and methods, used by public authorities in the process of implementing the directions of ensuring the resilience of the economy. Macroeconomic tools for ensuring resilience of the financial corporations sector are shown in Table 2.

Table 2

Macroeconomic tools for ensuring resilience of the financial corporations sector

\begin{tabular}{|c|c|c|}
\hline No. & Areas of ensuring resilience & Macroeconomic tools \\
\hline 1 & Economic stimulus packages & $\begin{array}{l}\text { Redemption by the state of bad loans from banks in exchange for their shareholdings. } \\
\text { Full deposit protection. }\end{array}$ \\
\hline 2 & Attractive credit conditions & State liquidity support: overnight credit, refinancing loans, direct repo operations. \\
\hline 3 & Tax and investment benefits & $\begin{array}{l}\text { Investment transaction tax benefits. } \\
\text { Short-term income tax benefits. }\end{array}$ \\
\hline 4 & Promoting innovation & Budget financing of financial innovations. \\
\hline 5 & Compensation mechanisms & Recapitalization of financial institutions. \\
\hline 6 & International financial support & $\begin{array}{l}\text { IMF Technical assistance. } \\
\text { Donor international assistance. }\end{array}$ \\
\hline
\end{tabular}

In 2008, the global financial and economic crisis led to an irreversible financial loss for businesses and citizens, which amounted to about one trillion dollars. The bankruptcy of the American bank Lehman Brothers has had a devastating impact on the development of the financial corporations sector and the global economy as a whole. This episode made the public aware of potential weaknesses of the mechanism for ensuring the resilience of the financial corporations.

The main measures of state support in the period of shock influences on the financial corporations sector should be aimed at preserving the funds of citizens and business, as well as to help banks stay "afloat". A key tool to keep safe funds of citizens and businesses is the introduction of a regime of full guarantee of deposits of individuals and legal entities. Deposit guarantee is a system of legal rules and mechanisms, aimed at generating and mobilizing savings to protect the banking system from financial crises, and protect small investors from risks that they are unable to evaluate and take into account in their investment decisions. A full guarantee of government deposits means that in the event of a banking crisis or bankruptcy of financial institutions, the government will pay its depositors the full amount of the deposit. Providing a $100 \%$ guarantee for the return of deposits will increase the confidence of individuals and businesses in banking institutions, which will encourage the attraction of new depositors.

In order to ensure the stable operation of banks in terms of shock influences, the government can use the tool of state repurchase of "bad" loans of enterprises in exchange for their stakes. Bad loans mean loans, issued to individuals and legal entities and payments for which they are delayed or repayable. Bad can be considered loans, even if the collateral under which they were issued was significantly depreciated.The criterion for assigning loans to this category is determined by each bank, based on its own financial situation. However, when banks are crowded with non-performing loans, they cannot and do not want to issue new loans.

The system of redemption of bad loans would create adequate incentives for banks, enterprises and the state. Banks with government guarantees would be more willing to lend to enterprises of the real sector. Businesses would be more responsible for doing business and repaying loans, as they will take the risk of losing control of the business or part of its income.The state would be able to replenish its own state property fund with profitable assets. The faster the government will help banks reduce the level of bad loans, the faster economic growth will recover. 
In the context of the direction of providing attractive lending conditions, let us consider the tool of state support for the liquidity of financial institutions. The liquidity of a financial institution depends on a sufficient amount of liquid resources, that is, the ability to quickly and with minimal losses translate assets into cash. In order to regulate the current liquidity of banks, the following liquidity support tools are provided:

- overnight loan is an interbank loan, which is provided on the shortest possible time - until the next business day. The purpose of such loans is to smooth temporary fluctuations in banks' liquidity and to promptly regulate the monetary market [16];

- refinancing loan - provided by the central bank to support the liquidity of banking institutions in case of unexpected and temporary shortages due to unplanned outflow of resources (withdrawal of deposits) or non-return on fixed term funds from active transactions (loans, securities). The bank refinancing mechanism is one of the key elements in ensuring the stability of the national currency [17];

- direct REPO operation is a financial transaction, which consists of two parts and under which a single general agreement is concluded between market participants for the sale (purchase) of securities for a certain period with a commitment to repurchase (purchase) on time or, at the request of either party, at a pre-determined price. By its economic nature, a REPO transaction is a credit transaction, in which securities are used as collateral. These transactions are irregular and aim at balancing unexpected liquidity fluctuations [18].

Due to the fact that banking institutions are the foundation of the country's financial system and the entire economy can suffer from their bankruptcy, regulation of banking investments is gaining importance. The introduction of tax benefits on investment transactions is a tool that will increase the value of the investment portfolio of banking institutions.

It is worth noting, that bank investment is an indirect driver of growth for the entire national economy. In the financial and economic crisis or economic downturn banking investments must have a growing dynamic. In the face of economic uncertainty, banking institutions reduce their lending volumes, as a result, their profits are reduced. Banks need to increase their investment to cover profit shortfall. The introduction of tax incentives for investment operations of banking institutions will ensure an adequate level of their profits and the banking sector as a whole.

In order to ensure the resilience of the financial corporations sector in times of financial instability, the state should introduce short-term income tax exemptions, namely the possible introduction of a special rate for a certain type of taxpayers. It is worth considering the option of differentiated tax rates, depending on the particular activity of a bank. It is also worth considering to lowering the income tax rate for banks that provide long-term government-targeted loans, for example, road construction under public-private partnerships. Changes in taxation of banks will allow the state to control (stimulate) certain directions of the activity of the banking sector and to enhance the interests of banks in increasing the business activity. The introduction of income tax benefits should be of a short-term nature, since after a certain time interval, it is necessary to analyze the performance of the bank, on the basis of which the decision to prolong or terminate the privilege is made.

In order to ensure the resilience of the financial corporations sector, it is also necessary to create conditions for the introduction and development of financial innovations, as they are one of the key elements of the development of the financial corporations sector. Financial innovation is understood implemented in the form of a new financial product or operations, the end result of innovative activities in the financial sector. Financial innovation is also seen as a catalyst for the economy, which is a new financial product or process that has different functions in terms of generating additional liquidity [19], ensuring market transparency, availability of information [20]. Financial innovations make it possible to improve the work of financial institutions, offering customers more products and services to maximize profits at the accordingly level of risk.

Budget financing of financial innovations is a tool of state non-repayable financial support. Innovation financing is the process of securing and using money, that focus on the design, creation, implementation of new products, technologies and services. Government support for innovation at the expense of budget funds is widely used in the world. For example, in the US and France, direct government funding accounts for $50 \%$ of the cost of creating new products and technologies [21]. 
Budget financing volumes, sufficient to create financial innovation, can provide the competitiveness of products and services, provided by the financial corporations sector.

In times of crisis, recapitalization is one of the key tools to support the activities of financial institutions. In the face of shock influences, when risks in the financial corporations sector increase, the quality of the loan portfolio deteriorates and the number of outstanding loans is increases, banking institutions can cover the risks at the expense of equity. In order for the bank not to go bankrupt, its level of equity must be maintained no lower than the value, determined by the requirements for adequacy of equity. In order to increase the level of equity capital, the bank recapitalizes.

Recapitalization is a process of raising the level of own funds of banking institutions. Recapitalization involves changing the capital structure of a bank or financial institution by converting securities, for example:

- bond swaps;

- transfer, based on appropriate procedures of all or part of the shares of the bank or financial institution to other owners;

- government buyout of banks by exchanging their assets for domestic government bonds, followed by monetization their by the central bank.

Next, consider tools such as IMF technical assistance and donor international assistance in the area of international financial support. Technical assistance is provided by the IMF on the basis of member states' requests and is intended to facilitate the development of particular sectors of the economy through training, consultancy, seminars and conferences. For example, for training in the framework of technical assistance, the IMF Institute was established in Washington to organize courses and seminars on civil servant training.

Technical assistance to the financial corporations sector is aimed at providing guidance on financial policy, monetary policy, central bank activity and external debt management. The technical assistance, provided to countries, helps ensure that the IMF's recommendations for financial stability are effective, allows central governments to stay up-to-date on innovations and risks in the global economy, it also helps in solving problems, which are related to the emergence of crises.

Donor international assistance is free of charge and is provided to promote the socio-economic development of developing countries. Donors can be both international financial institutions and individual countries. The following major groups of international donors can be identified by a source of capital: intergovernmental organizations, government donors, public donors, private donors, corporate donors. Donor international assistance involves the provision resources on a royalty-free and non-refundable basis, to support the country in accordance with international treaties.

The state is responsible for implementing macroeconomic tools that must meet the current needs of the financial corporations sector and contribute to the development of the economy as a whole. In the face of financial instability, macroeconomic tools will enhance the performance and economic growth of the financial corporation sector.

\section{Conclusion}

1. Macroeconomic tools are a system of means, aimed at implementing the areas of resilience of the financial corporations sector. In the face of shock influences, the implementation of macroeconomic tools will contribute to the stable development and economic growth of the financial corporations sector.

2. The system of macroeconomic tools for ensuring resilience of the financial corporations sector is aimed at achieving three key objectives: increase in profit volume, increase of solvency and increase of efficiency of activity of financial corporations.

3. The effectiveness of macroeconomic tools for ensuring resilience of the financial corporations sector depends on the management mechanism that implements them. The structure of the governance mechanism should be characterized by such components as event planning, financing and incentives.The completeness of these components in the legislation will facilitate the effective implementation of macroeconomic tools in the context of shock influences.

4. It should be borne in mind, that each of the macroeconomic tools attracts in the joint movement a mass of additional components and factors that have an additional impact on the de- 
velopment of the financial corporations sector. Public authorities should focus more on exploring possible scenarios for the economic development of the financial corporations sector, with a view to planning measures to implement macroeconomic tools.

\section{References}

[1] OECD Home. Economic resilience: Vulnerability indicators (2017). Available at: https://www.oecd.org/eco/growth/economicresilience.htm

[2] Economic resilience in EMU. European Commission.Directorate general economic and financial affairs (2017). Brussels, 13. Available at: https://www.consilium.europa.eu/media/23535/eurogroup-15-september-item1-com-note-economic-resilience-in-emu.pdf

[3] International Monetary Fund. About the IMF. How we do it. Available at: https://www.imf.org/external/about/howwedo.htm

[4] Boiko, A. (2017). Zabezpechennya stiykosti natsionalnoyi ekonomiky. Zovnishnya torhivlya: ekonomika, finansy, pravo, 4 (93), 16-27. Available at: http://zt.knteu.kiev.ua/files/2017/04(93)/02.pdf

[5] Kozlovskiy, S. (2013). Indykatyvni metody zabezpechennya stiykosti ekonomiky Ukrayiny. Efektyvna ekonomika, 10. Available at: http://www.economy.nayka.com.ua/?op=1\&z=2373

[6] Argyroudis, S. (2019). Tools for resilience assessment: developments, limitations and future needs. 2nd International Conference on Natural Hazards and Infrastructure. Chania. Available at: https://www.researchgate.net/publication/334173141_Tools_ for_Resilience_Assessment_Developments_Limitations_and_Future_Needs

[7] Klasyfikatsiya instytutsiynykh sektoriv ekonomiky Ukrayiny (2014). Nakaz Derzhavnoyi sluzhby statystyky Ukrayiny No. 378. 03.12.2014. Available at: http://www.ukrstat.gov.ua/klasf/st_kls/op_kise_2016.htm

[8] The System of National Accounts 2008 (2008). SNA. Available at: https://unstats.un.org/unsd/nationalaccount/sna2008.asp

[9] Ernst \& Young. Perspectives: operational resilience in financial services (2019). Available at: https://www.parthenon.ey.com/ Publication/vwLUAssets/ey-perspectives-operational-resilience-in-financial-services/\$FILE/ey-perspectives-operationalresilience-in-financial-services.pdf

[10] KPMG Global. Operational Resilience (2018). Available at: https:/home.kpmg/xx/en/home/insights/2018/07/operationalresilience-fs.html

[11] Operational Resilience (2019). PricewaterhouseCoopers. Available at: https://www.pwc.ch/en/publications/2019/operationalresilience_final_web-singles.pdf

[12] Internal audit hot topics for 2020 planning (2020). BDO. Available at: https://www.bdo.co.uk/getmedia/f279e7cf-b2e6-4d12b9c7-feb3b5154283/Internal-Audit-Hot-Topics-2019-BDO.pdf.aspx

[13] IT change and operational resilience in financial services (2019). Deloitte. Available at: https://blogs.deloitte.co.uk/financialservices/2019/06/ecrs-blog-it-change-and-operational-resilience-in-financial-services.html

[14] Striving for operational resilience: the questions boards and senior management should ask (2019). Oliver Wyman. Available at: https://www.oliverwyman.com/our-expertise/insights/2019/may/striving-for-operational-resilience.html

[15] Milliman. Operational resilience in an ever changing landscape (2019). Available at: http://uk.milliman.com/uploadedFiles/ insight/2019/Operational-Resilience.pdf

[16] Pro zatverdzhennya Polozhennya pro rehulyuvannya Natsionalnym bankom Ukrayiny likvidnosti bankiv Ukrayiny (2009). Postanova Natsionalnoho banku Ukrayiny No. 259. 30.04.2009. Available at: https://zakon.rada.gov.ua/laws/show/z0410-09

[17] Pidtrymka likvidnosti bankivskoyi systemy Natsionalnym bankom Ukrayiny (2009). Ofitsiyne Internet-predstavnytstvo NBU. Available at: https://old.bank.gov.ua/control/uk/publish/article?art_id=84310\&cat_id=70880

[18] Operatsiyi repo. Instrumenty monetarnoyi polityky. NBU. Available at: https://old.bank.gov.ua/control/uk/publish/article?art_ id $=107598 \&$ cat id $=46470$

[19] Janíčko, M. (2015). Mainstream Versus Heterodox View on Financial Innovation. Procedia Economics and Finance, 30, 352363. doi: http://doi.org/10.1016/s2212-5671(15)01302-7

[20] Zavolokina, L., Dolata, M., Schwabe, G. (2016). The FinTech phenomenon: antecedents of financial innovation perceived by the popular press. Financial Innovation, 2 (1). doi: http://doi.org/10.1186/s40854-016-0036-7

[21] Kvasha, T., Pysarenko, T. (2018). Stan innovatsiynoyi diyalnosti ta diyalnosti u sferi transferu tekhnolohiy v Ukrayini u 2017 rotsi. Kyiv: Ukrayinskiy instytut naukovo-tekhnichnoyi ekspertyzy ta informatsiyi, 98. Available at: https://mon.gov.ua/storage/app/media/innovatsii-transfer-tehnologiy/monitoring-prioritet/stan-id-2017-f.pdf 